\title{
Nutrition for Preterm Infants: 75 Years of History
}

\author{
Johannes B. van Goudoever \\ Emma Children's Hospital - AMC \& VU University Medical Center, Amsterdam, The Netherlands
}

\section{Key Messages}

- Early nutrition has a huge impact on the short- and long-term health of preterm infants.

- Human milk has been and is again the preferred enteral supply, although fortification is required to meet the requirements.

\section{Keywords}

Iron · Folate · Human milk · Donor milk · Fortifier · Probiotics

\begin{abstract}
As technology has advanced, survival rates of preterm infants have improved dramatically. Human milk was the primary source of enteral nutrition during the early days of neonatology, but the HIV/AIDS epidemic resulted in an increased use of preterm formula. More recently, the benefits of human milk were rediscovered, resulting in increased use of donor human milk as well. The awareness that human milk does not contain the amounts of nutrients to meet the high requirements of infants born premature resulted in the de-
\end{abstract}

velopment of human milk fortifiers. The development of these fortifiers is still ongoing, as are alternative methods of pasteurization of donor milk. Those initiatives will increase the use of human milk with consequently short- and longterm benefits for preterm infants.

(c) 2018 The Author(s)

Published by S. Karger AG, Basel

\section{Introduction}

Modern preterm infant care has its origins at the Hôpital de la Charité in Paris. Pierre Budin, influenced by the former head midwife of the Maternité, Madame Henry, installed the first specialized care unit for "weaklings," as underweight infants were then referred to, in 1893 (Fig. 1). Budin was then called as head of Obstectrics at Hôpital de la Maternité in 1898. Under his direction, both hospitals became the world's first centers of specialized study on caring for preterm infants. In his lectures to students, published in 1890, Baudin highlighted 3 main basic problems for preterm infants:

- Risk of hypothermia through cooling

- Vulnerability to infections

- Feeding 


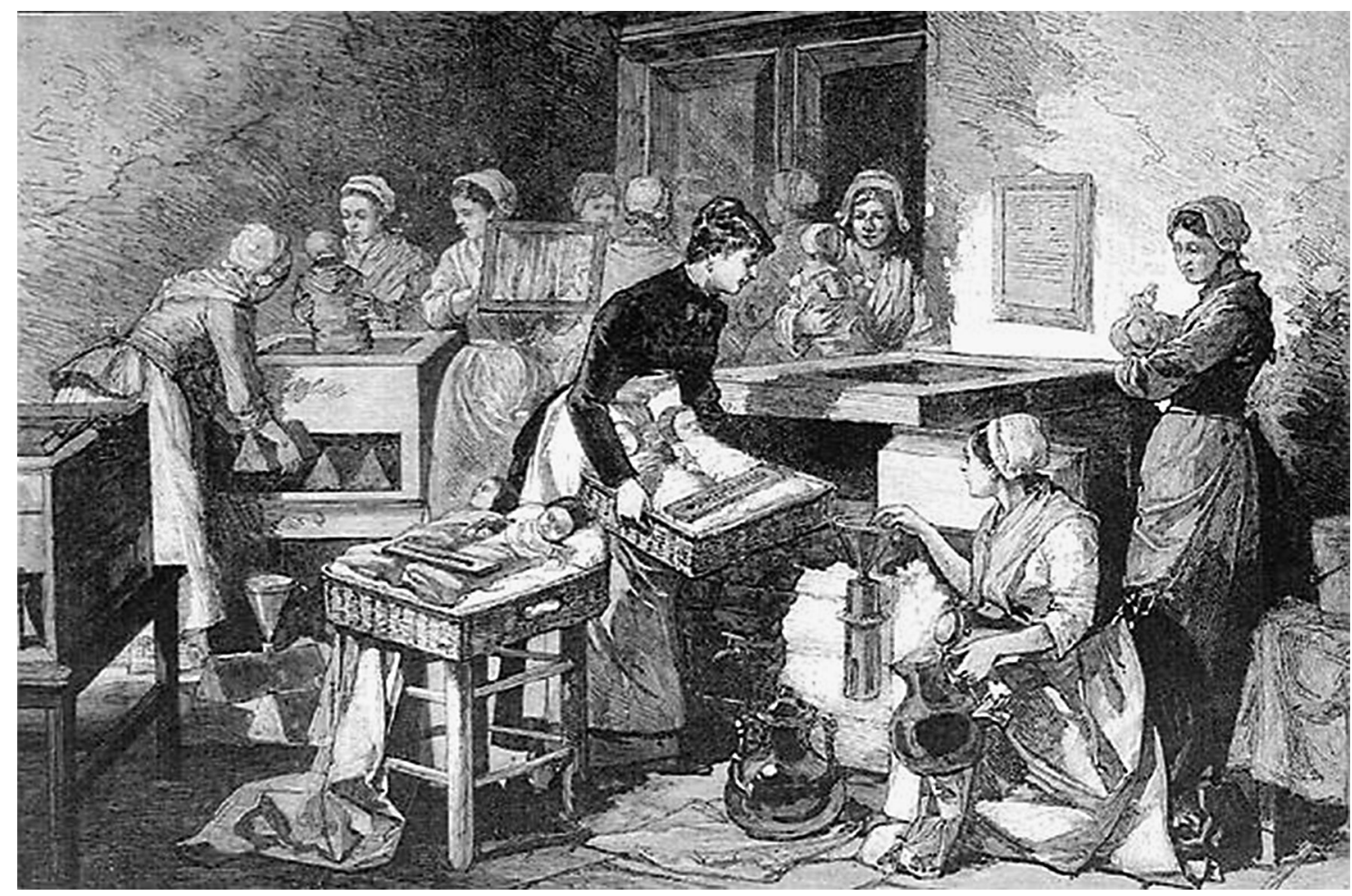

Fig. 1. "Maternité de Paris” from The Illustrated London News, March 8th, 1884.

Although the first neonatal unit was already opened in 1893 , it took a long time before anything was published on preterm nutrition in the scientific literature and especially in this journal.

The First Article on Preterm Nutrition in Annales

Nestlé (Annals of Nutrition and Metabolism)

The first article that appeared in the Annals of Nutrition and Metabolism which was somehow related to nutrition and neonates was published by Zittoun et al. [1] from France in 1983. They investigated the effect of iron supplementation during pregnancy, and this placebocontrolled (!) trial demonstrated that iron supplements to iron-deprived mothers had no effect on the ferritin status of the newborn, on the folate status of the mothers or infants, or on the frequency of obstetrical complications. A significant relationship was found between maternal folate levels and length of gestation. The authors concluded that folate supplementation during pregnancy might reduce the incidence of premature delivery.

\section{Folate and Iron: Present Knowledge and Advice}

That folate was important became more obvious in the following years, but not so much with regard to anemia, but as an actor in prevention of neural tube defects. Unambiguous evidence of the effectiveness of periconceptional folic acid in preventing neural tube defects has been available since 1991 [2] and is still undisputed [3]. The first governments to formulate a periconceptional folic acid supplementation policy were the United Kingdom (1992), Ireland (1993), and the Netherlands (1993); six more (Switzerland 1996, Denmark 1997, Norway 1998, Portugal 1998, France 2000, and Spain 2001) followed. Despite firm evidence, adherence is low.

Many studies have appeared regarding maternal iron supplementation since 1983, and at present it is clear that iron supplementation reduces maternal anemia incidence in pregnancy but the effects on infant outcomes are less clear [4]. Compared with controls, women taking iron supplements less frequently had low-birth-weight newborns (8.4 vs. $10.3 \%$, average RR $0.84,95 \%$ CI $0.69-$ $1.03,11$ trials, 17,613 women; low-quality evidence) and preterm babies (RR 0.93, 95\% CI 0.84-1.03, 13 trials, 19,286 women; moderate-quality evidence). 
Preterm and low-birth-weight infants are at high risk of iron deficiency due to low iron stores at birth and higher iron requirements due to rapid growth. Already in 1971, Lundstrom et al. [5] demonstrated that $2 \mathrm{mg} / \mathrm{kg}$ was adequate to prevent anemia in infants with a birth weight of 1,000-2,000 $\mathrm{g}$ at 3 months of age. The randomization procedure was that infants with odd birth dates received $2 \mathrm{mg}$ iron as ferrous sulfate $/ \mathrm{kg} /$ day starting at 0.5 months; those with even birth dates received no additional iron unless they developed anemia. Interestingly, almost 50 years later, with many additional randomized controlled trials performed, the most recent recommendation (published in the Annals of Nutrition an Metabolism December 2017 issue) is almost identical: $1-3 \mathrm{mg} / \mathrm{kg} / \mathrm{day}$ (1-2 mg for marginally low birth weight and 2-3 mg for very low birth weight) is needed to effectively prevent iron deficiency [6]. There is some recent evidence that these levels of iron intake will prevent some of the negative health consequences associated with low birth weight, especially behavioral problems and other neurodevelopmental outcomes and possibly even hypertension.

\section{Milestones in Enteral Preterm Nutrition}

\section{Preterm Formula}

Since the early days of caring for preterm infants, it has been widely held that human milk was the food of choice for these infants. This belief, however, has not prevented some pediatricians from suggesting that human milk might not in fact be the ideal food on the grounds that its low protein content is insufficient for growth requirements. Especially the lack of adequate protein content to meet the requirements has driven the development of formulas especially designed for preterm infants. One of the earlier publications on protein content of preterm formula originated from Professor Peter Davies in 1975 [7]. He acknowledged that adequate protein intake in the early weeks of life is necessary if growth is to proceed normally. The question of optimum protein requirements for preterm infants is therefore an important one. He investigated 106 preterm infants who were fed 1 of 3 isocaloric milks for a period of 2 months. Milk A was high-protein milk (21\% calories as protein), milk B was medium-protein milk (15\% calories as protein), and milk $\mathrm{C}$ was human breast milk (7\% calories as protein). Changes in weight, length, head circumference, and triceps skinfold thickness were evaluated. The results suggested that though human milk was adequate for the growth needs of the more mature preterm infants (33-36 weeks' gestation), less mature infants (28-32 weeks' gestation) fed human milk failed to achieve adequate growth rates compared with infants on higher protein intakes. At the same time, a landmark paper by Goldman et al. [8] appeared in the Journal of Pediatrics, warning about very high protein intake because of deleterious effects on IQ development. This study was a follow-up of an earlier double-blinded study, performed in 1963 [9], where less edema was observed in infants fed $6 \mathrm{~g} / \mathrm{kg} /$ day of cow's milk protein, but more fever, lethargy, and poor feeding behavior as well as higher levels of plasma protein than the infants fed $3 \mathrm{~g} / \mathrm{kg} /$ day of cow's milk protein in the direct postnatal phase. Specifically infants with a birth weight $<1,300 \mathrm{~g}$ were at risk of developing strabismus and low IQ scores.

As product development enhanced, casein whey fractions were modified to increase tolerability, many studies addressed the optimal intake and relationship between energy and protein intakes.

Cow's milk contains approximately $20 \%$ whey protein and $80 \%$ casein proteins, whereas formulas were gradually modified to a ratio of whey proteins to caseins of 60:40. These modifications resulted in a plasma amino acid pattern more resembling that of a fully breastfed infant [10]. Pivotal in that development were the studies by Kashyap and Heird [11, 12] who studied the effects of varying protein and energy intakes. These studies followed the observation that premature infants have high rates of energy expenditure, using different techniques $[13,14]$. Acknowledging that sufficient energy must be provided for maintaining high rates of protein synthesis, many studies were undertaken to determine the optimal protein energy ratio in various groups [15]. This resulted in recommendations that enterally fed infants should receive $110-135 \mathrm{kcal} / \mathrm{kg} / \mathrm{day}$ and at least $3.6 \mathrm{~g} / \mathrm{kg} / \mathrm{day}$ of proteins [16].

While the breast milk of mothers who deliver preterm contains higher amounts of proteins, this effect diminishes after approximately 1 month. The quality of the milk may also be different, especially with regard to the immune proteins $[17,18]$. These observations led to a general believe that human milk did not meet the requirements of rapidly developing preterm infants with subsequent effects on growth and development. This led to the development of formulas specifically designed for pre- 
Fig. 2. Human Milk Center in Amsterdam 70 years ago.
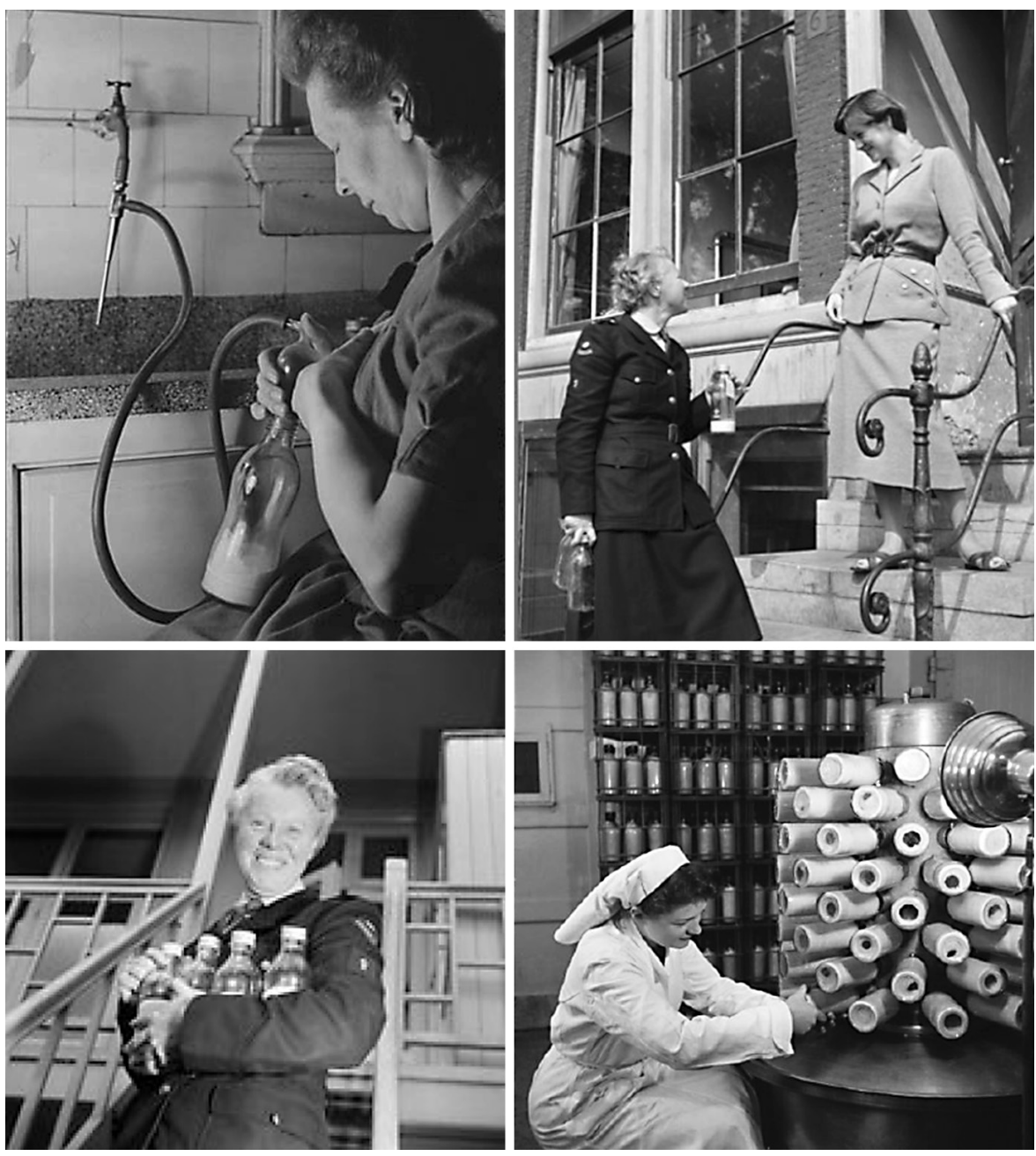

term infants. An important paper published in The Lancet in 1990 [19] suggested that infants fed a higher nutrient density formula for a period as short as 1 month had long lasting effects on neurodevelopment and regional brain volumes [19-21]. Preterm formula became standard feeding in many neonatal units, and rates of infants fed own mother's milk declined significantly. Editorials with suggestive titles such as "Breast Not Necessarily Best" appeared in 1998, in an era in which AIDS and its effects became very apparent [22]. However, already 5 years later, arguments were made to use own mother's milk because of evidence that human milk reduced rates of infections and necrotizing enterocolitis (NEC) and enhanced the developmental outcome of preterm infants [23].

\section{Donor Milk}

Approximately 75 years ago, human donor milk became increasingly popular throughout Europe. Especially after the Second World War, many countries started a human milk bank. Figure 2 shows the workflow in these days. Milk was collected at home, brought to a central place (blood bank or hospital) and vacuum dried. Powered human milk was available for preterm born infants and neonates with gastrointestinal problems.

With the discovery of HIV and knowing that breast milk could serve as transmitter, many milk banks closed throughout Europe. Concomitantly, preterm formula was developed. Although preterm formula administration results in higher in-hospital growth rates than own mother's milk, the use of cow's milk-based preterm formula when own mother's milk was not available has not been without controversy. Already in 1990, Lucas and Cole [24] reported that in exclusively formula-fed babies, NEC was 6-10 times more common than in those fed breast milk alone and 3 times more common than in those who received formula plus breast milk. Numerous van Goudoever 


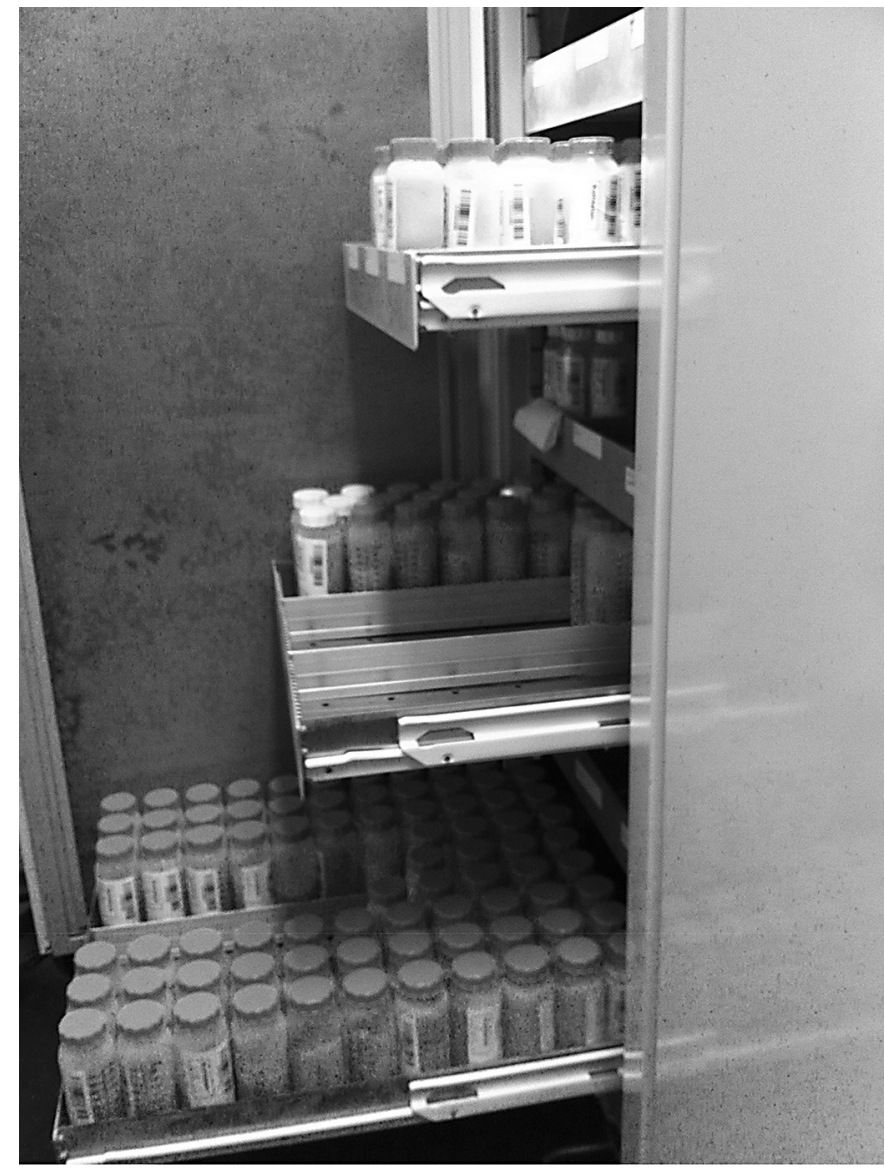

Fig. 3. Present human milk bank in Amsterdam, The Netherlands.

papers report also an association with a lower incidence of nosocomial infections when own mother's milk is fed instead of preterm formula [e.g., 25]. Following these observations and implementing methods to prevent the transmission of contagious microbes in human milk, the use of donor milk as substitute for own mother's milk became increasingly popular again. At present, more than 500 donor milk banks are operating around the world, most of them in Europe and South America. Processing techniques have been optimized and guidelines on the preferential use have been issued [26]. Preservation techniques have been optimized (Fig. 3), increasing the length of storage and therewith the price [27].

The exact mechanism as to how human milk exerts a beneficial effect on the prevalence of NEC is at present unknown. Many factors might contribute to the particularly increased risk of preterm infants to develop NEC (Table 1). The altered microbiome in addition to an altered immune response may be the two most important mechanisms.

Nutrition for Preterm Infants
The colonization of the gut of the preterm infant is progressing slower than that of a term infant, while the numbers of microbiota are reduced and less diverse. That may be influenced by the high prevalence of antibiotic use in the first period of life [28], the environment (a NICU with many selected pathogens [29]), the altered mucin production rates and quality [30], the motility [31], and the immune system.

The fetal immune system is generally characterized as tolerogenic to prevent graft-versus-host responses during pregnancy. T cells in the fetal intestinal mucosa allow for early compartmentalization of TH1 responses, predominated by TNF- $\alpha$ and IL-2-producing T cells early in human development $[32,33]$. These fetal mucosal TH1 cells can contribute to mucosal development by producing TNF- $\alpha$, which promotes the outgrowth of fetal intestinal epithelial stem cells. However, when this process is disturbed by preterm birth, preferential induction of TH1 cells may instigate an inflammatory cascade providing the underlying conditions for NEC, which might explain why premature infants are more susceptible to NEC than term infants are.

Cow's milk protein might cause an immunomodulatory effect, for instance an increased production of TNF- $\alpha$, which subsequently may result in a disturbed outgrowth of these intestinal epithelial stem cells with consequently an inflammatory bowel condition. Some evidence was provided by small studies suggesting that an exclusive human milk diet would results in lower NEC rates [34]. A recent randomized controlled trial, however, did not suggest that cow's milk protein exposure resulted in a higher rate of NEC, when compared to pasteurized donor milk provided in the first 10 days of life [35].

Thus, most likely, several factors present, especially in unpasteurized milk, exert a beneficial effect, although results from the available high-quality studies are not overwhelming. Schanler et al. [36] did not find an effect on NEC in their blinded randomized controlled trial, but the most recent blinded randomized controlled trial did find a significant association between donor milk and the incidence of NEC [37]. These developments, the cost-effectiveness of human donor milk [38], and the potential benefits in the long term will probably lead to a policy where the use of preterm formula will only be limited to those infants of whom the parents do not want to use donor milk [39-41]. New techniques of pasteurization will increase the effectiveness of donor milk [42].

\section{Fortification of Human Milk}

With the knowledge that human milk reduces NEC and nosocomial infections and the fact that nutrient re- 
quirements are not met with human milk alone, the usage of fortifiers became increasingly popular at the end of the 20th century. Variability in the composition of human milk and the high nutrient demands of preterm infants was acknowledged and commercial fortifiers became in vogue.

The first study on the use of human milk fortification was published in 1986 by Modanlou et al. [43]. They compared small groups of infants fed either preterm human milk $(n=10)$, fortified preterm human milk $(n=8)$, or premature formula $(n=12)$ and concluded that weight gain rates were similar in the infants fed preterm formula and fortified human milk, but infants fed preterm mother's milk had lower rates of weight gain. Fourteen highquality studies followed and current practice is that preterm infants receive fortified human milk. The observation is that fortification leads to higher in-hospital growth, but there are no effects on growth or neurodevelopment observed beyond infancy [44]. As time will proceed, not only cow's milk proteins, vitamins, and minerals are supplied, but also fat and one might think of specific bioactive products. Lactoferrin is such a promising substance that might be added to the fortifiers in the future [45].

\section{Probiotics}

The knowledge that human milk contains bacteria originates from the 1950s [e.g., 46]. The first study that showed an effect of adding specific strains to preterm formula originated in the previous century [47]. Prior to that study, some reported the effect of adding probiotics on
Table 1. Contributing factors to the increased risk of preterm infants developing NEC

- Delayed and altered microbial colonization

- Altered mucin barrier

- Decreased gut motility

- Increased gut permeability

- Altered immune system

the microbiome [48-50]. Despite many trials that followed, and an overall clear effect of probiotic supplementation on reducing NEC incidence, probiotics were not used at all units. The heterogeneity of organisms and dosing regimens studied have prevented a species-specific treatment recommendation from being made so far [5154]. Furthermore, quality control of the available products remains an issue [55].

In conclusion, tremendous developments, both technological and nutritional, have been made, enabling higher survival rates but also higher quality of life. The revival of the use of human milk in the NICU will affect both these outcomes, certainly when the appropriate additives will be used.

\section{Disclosure Statement}

J.B. van Goudoever is a member of the National Health Council and director of the National Donor Milk Bank. The writing of this article was supported by Nestlé Nutrition Institute.

\section{References}

1 Zittoun J, Blot I, Hill C, Zittoun R, Papiernik E, Tchernia G: Iron supplements versus placebo during pregnancy: its effects on iron and folate status on mothers and newborns. Ann Nutr Metab 1983;27:320-327.

2 Prevention of neural tube defects: results of the Medical Research Council Vitamin Study. MRC Vitamin Study Research Group. Lancet 1991;338:131-137.

3 De-Regil LM, Pena-Rosas JP, FernandezGaxiola AC, Rayco-Solon P: Effects and safety of periconceptional oral folate supplementation for preventing birth defects. Cochrane Database Syst Rev 2015:CD007950.

4 Pena-Rosas JP, De-Regil LM, Garcia-Casal MN, Dowswell T: Daily oral iron supplementation during pregnancy. Cochrane Database Syst Rev 2015:CD004736.

5 Lundstrom U, Siimes MA, Dallman PR: At what age does iron supplementation become necessary in low-birth-weight infants? J Pediatr 1977;91:878-883.
6 Domellof M: Meeting the iron needs of low and very low birth weight infants. Ann Nutr Metab 2017;71(suppl 3):16-23.

7 Davies DP: Proceedings: Is human milk the best food for preterm infants? Arch Dis Child 1975;50:330.

8 Goldman HI, Goldman J, Kaufman I, Liebman OB: Late effects of early dietary protein intake on low-birth-weight infants. J Pediatr 1974;85:764-769.

9 Goldman HI, Freudenthal R, Holland B, Karelitz S: Clinical effects of two different levels of protein intake on low-birth-weight infants. J Pediatr 1969;74:881-889.

10 Kashyap S, Okamoto E, Kanaya S, Zucker C, Abildskov K, Dell RB, Heird WC: Protein quality in feeding low birth weight infants: a comparison of whey-predominant versus casein-predominant formulas. Pediatrics 1987; 79:748-755.
11 Kashyap S, Forsyth M, Zucker C, Ramakrishnan R, Dell RB, Heird WC: Effects of varying protein and energy intakes on growth and metabolic response in low birth weight infants. J Pediatr 1986;108:955-963.

12 Heird WC, Kashyap S, Gomez MR: Protein intake and energy requirements of the infant. Seminars in perinatology 1991;15:438-448.

13 Sauer PJ, Dane HJ, Visser HK: Longitudinal studies on metabolic rate, heat loss, and energy cost of growth in low birth weight infants. Pediatr Res 1984;18:254-259.

14 Westerterp KR, Lafeber HN, Sulkers EJ, Sauer PJ: Comparison of short term indirect calorimetry and doubly labeled water method for the assessment of energy expenditure in preterm infants. Biol Neonate 1991;60:75-82.

15 van Goudoever JB, Sulkers EJ, Lafeber HN, Sauer PJ: Short-term growth and substrate use in very-low-birth-weight infants fed formulas with different energy contents. Am J Clin Nutr 2000;71:816-821. 
16 Agostoni C, Buonocore G, Carnielli VP, De Curtis M, Darmaun D, Decsi T, Domellof M, Embleton ND, Fusch C, Genzel-Boroviczeny $\mathrm{O}$, et al: Enteral nutrient supply for preterm infants: commentary from the European Society of Paediatric Gastroenterology, Hepatology and Nutrition Committee on Nutrition. J Pediatr Gastroenterol Nutr 2010;50:85-91.

17 Dingess KA, de Waard M, Boeren S, Vervoort J, Lambers TT, van Goudoever JB, Hettinga K: Human milk peptides differentiate between the preterm and term infant and across varying lactational stages. Food Funct 2017;8: 3769-3782.

18 Zhang L, de Waard M, Verheijen H, Boeren S, Hageman JA, van Hooijdonk T, Vervoort J, van Goudoever JB, Hettinga K: Changes over lactation in breast milk serum proteins involved in the maturation of immune and digestive system of the infant. J Proteomics 2016;147:40-47.

19 Lucas A, Morley R, Cole TJ, Gore SM, Lucas PJ, Crowle P, Pearse R, Boon AJ, Powell R: Early diet in preterm babies and developmental status at 18 months. Lancet 1990;335: 1477-1481.

20 Isaacs EB, Gadian DG, Sabatini S, Chong WK, Quinn BT, Fischl BR, Lucas A: The effect of early human diet on caudate volumes and IQ. Pediatr Res 2008;63:308-314.

21 Isaacs EB, Morley R, Lucas A: Early diet and general cognitive outcome at adolescence in children born at or below 30 weeks gestation. J Pediatr 2009;155:229-234.

22 Breast not necessarily best. Lancet $1988 ; 1$ : 624-626.

23 Williams AF: Human milk and the preterm baby. BMI 1993;306:1628-1629.

24 Lucas A, Cole TJ: Breast milk and neonatal necrotising enterocolitis. Lancet 1990;336: 1519-1523.

25 Corpeleijn WE, Kouwenhoven SM, Paap MC, van Vliet I, Scheerder I, Muizer Y, Helder OK, van Goudoever JB, Vermeulen MJ: Intake of own mother's milk during the first days of life is associated with decreased morbidity and mortality in very low birth weight infants during the first 60 days of life. Neonatology 2012; 102:276-281.

26 Nutrition ECo, Arslanoglu S, Corpeleijn W, Moro G, Braegger C, Campoy C, Colomb V, Decsi T, Domellof M, Fewtrell M, et al: Donor human milk for preterm infants: current evidence and research directions. J Pediatr Gastroenterol Nutr 2013;57:535-542.

27 de Waard M, Mank E, van Dijk K, Schoonderwoerd A, van Goudoever JB: Holder-pasteurized human donor milk: how long can it be preserved? J Pediatr Gastroenterol Nutr 2018; 66:479-483.

28 Gibson MK, Wang B, Ahmadi S, Burnham CA, Tarr PI, Warner BB, Dantas G: Developmental dynamics of the preterm infant gut microbiota and antibiotic resistome. Nat Microbiol 2016;1:16024.

29 Roach DJ, Burton JN, Lee C, Stackhouse B, Butler-Wu SM, Cookson BT, Shendure J, Sali- pante SJ: A year of infection in the intensive care unit: prospective whole genome sequencing of bacterial clinical isolates reveals cryptic transmissions and novel microbiota. PLoS Genet 2015;11:e1005413.

30 Schaart MW, de Bruijn AC, Schierbeek H, Tibboel D, Renes IB, van Goudoever JB: Small intestinal MUC2 synthesis in human preterm infants. Am J Physiol Gastrointest Liver Physiol 2009;296:G1085-1090.

31 Berseth CL: Gastrointestinal motility in the neonate. Clin Perinatol 1996;23:179-190.

32 Michaelsson J, Mold JE, McCune JM, Nixon DF: Regulation of $\mathrm{T}$ cell responses in the developing human fetus. J Immunol 2006;176: 5741-5748.

33 Thome JJ, Bickham KL, Ohmura Y, Kubota M, Matsuoka N, Gordon C, Granot T, Griesemer A, Lerner H, Kato T, et al: Early-life compartmentalization of human $\mathrm{T}$ cell differentiation and regulatory function in mucosal and lymphoid tissues. Nat Med 2016;22:7277.

34 Abrams SA, Schanler RJ, Lee ML, Rechtman DJ: Greater mortality and morbidity in extremely preterm infants fed a diet containing cow milk protein products. Breastfeed Med 2014;9:281-285.

35 Corpeleijn WE, de Waard M, Christmann V, van Goudoever JB, Jansen-van der Weide MC, Kooi EM, Koper JF, Kouwenhoven SM, Lafeber HN, Mank E, et al: Effect of donor milk on severe infections and mortality in very low-birth-weight infants: The Early Nutrition Study Randomized Clinical Trial. JAMA Pediatr 2016;170:654-661.

36 Schanler RJ, Lau C, Hurst NM, Smith EO: Randomized trial of donor human milk versus preterm formula as substitutes for mothers' own milk in the feeding of extremely premature infants. Pediatrics 2005;116:400-406.

37 O’Connor DL, Gibbins S, Kiss A, Bando N, Brennan-Donnan J, Ng E, Campbell DM, Vaz S, Fusch C, Asztalos E, et al: Effect of supplemental donor human milk compared with preterm formula on neurodevelopment of very low-birth-weight infants at 18 months: a randomized clinical trial. JAMA 2016;316: 1897-1905.

38 Buckle A, Taylor C: Cost and cost-effectiveness of donor human milk to prevent necrotizing enterocolitis: systematic review. Breastfeed Med 2017;12:528-536.

39 Haiden N, Ziegler EE: Human milk banking. Ann Nutr Metab 2016;69(suppl 2):8-15.

40 Thorley V: Milk siblingship, religious and secular: History, applications, and implications for practice. Women Birth 2014;27:e1619.

41 Khalil A, Buffin R, Sanlaville D, Picaud JC: Milk kinship is not an obstacle to using donor human milk to feed preterm infants in Muslim countries. Acta Paediatr 2016;105:462467.

42 Picaud JC, Buffin R: Human milk-treatment and quality of banked human milk. Clin Perinatol 2017;44:95-119.
43 Modanlou HD, Lim MO, Hansen JW, Sickles V: Growth, biochemical status, and mineral metabolism in very-low-birth-weight infants receiving fortified preterm human milk. J Pediatr Gastroenterol Nutr 1986;5:762-767.

44 Brown JV, Embleton ND, Harding JE, McGuire W: Multi-nutrient fortification of human milk for preterm infants. Cochrane $\mathrm{Da}$ tabase Syst Rev 2016:CD000343.

45 Pammi M, Suresh G: Enteral lactoferrin supplementation for prevention of sepsis and necrotizing enterocolitis in preterm infants. Cochrane Database Syst Rev 2017;6: CD007137.

46 Kristen G, Petuely F: Investigations in the bifidus factor; human milk and bifidus bacteria. Osterr Z Kinderheilkd Kinderfuersorge 1950; 4:121-134.

47 Hoyos AB: Reduced incidence of necrotizing enterocolitis associated with enteral administration of Lactobacillus acidophilus and Bifidobacterium infantis to neonates in an intensive care unit. Int J Infect Dis 1999; 3:197-202.

48 Millar MR, Bacon C, Smith SL, Walker V, Hall MA: Enteral feeding of premature infants with Lactobacillus GG. Arch Dis Child 1993; 69(5 Spec No):483-487.

49 Kitajima H, Sumida Y, Tanaka R, Yuki N, Takayama H, Fujimura M: Early administration of Bifidobacterium breve to preterm infants: randomised controlled trial. Arch Dis Child 1997;76:F101-107.

50 Reuman PD, Duckworth DH, Smith KL, Kagan R, Bucciarelli RL, Ayoub EM: Lack of effect of Lactobacillus on gastrointestinal bacterial colonization in premature infants. Pediatr Infect Dis 1986;5:663-668.

51 Sawh SC, Deshpande S, Jansen S, Reynaert CJ, Jones PM: Prevention of necrotizing enterocolitis with probiotics: a systematic review and meta-analysis. PeerJ 2016;4:e2429.

52 AlFaleh K, Anabrees J: Probiotics for prevention of necrotizing enterocolitis in preterm infants. Cochrane Database Syst Rev 2014: CD005496.

53 Olsen R, Greisen G, Schroder M, Brok J: Prophylactic probiotics for preterm infants: a systematic review and meta-analysis of observational studies. Neonatology 2016;109:105112.

54 Mihatsch WA, Braegger CP, Decsi T, Kolacek $\mathrm{S}$, Lanzinger $\mathrm{H}$, Mayer B, Moreno LA, Pohlandt F, Puntis J, Shamir R, et al: Critical systematic review of the level of evidence for routine use of probiotics for reduction of mortality and prevention of necrotizing enterocolitis and sepsis in preterm infants. Clin Nutr 2012; 31:6-15.

55 Kolacek S, Hojsak I, Berni Canani R, Guarino A, Indrio F, Orel R, Pot B, Shamir R, Szajewska H, Vandenplas Y, et al: Commercial probiotic products: a call for improved quality control. A Position Paper by the ESPGHAN Working Group for Probiotics and Prebiotics. J Pediatr Gastroenterol Nutr 2017;65: 117-124. 